\title{
Effect of different protein and energy levels on growth performance and body composition of red tilapia
}

\author{
Mohamed Y. Abou Zead \\ World fish, Regional Research Center for Africa and west Asia, Abbassa, Sharkia, Egypt. \\ Corresponding author: myabouzead@yahoo.com
}

\begin{abstract}
A 8-weeks feeding trial was conducted to explain the most suitable levels of protein and energy for red tilapia fry reared in fresh water. Nine experimental diets of 25,30 and $35 \%$ crude protein and within each level, three levels of metabolizable energy (ME) 240,280 and $320 \mathrm{kcal} / 100 \mathrm{~g}$ diets were formulated. Red tilapia fry $(0.77 \mathrm{~g})$ fed the experimental diets at a daily rate of $20 \%$ (during the $1^{\text {st }}$ month) and then decreased to $10 \%$ ( $2^{\text {nd }}$ month) of the total biomass. The obtained results showed that, increasing dietary protein and energy levels significantly improved all growth parameters (body weight, body length, weight gain and specific growth rate) of red tilapia fry. Fish group fed the diet contained 35\% crude protein and $320 \mathrm{Kcal} \mathrm{ME} / 100 \mathrm{~g}$ showed the highest final body weight, body length, weight gain and specific growth rate while fish fed the diet contained $25 \%$ crude protein and $240 \mathrm{kcal}$ $\mathrm{ME} / 100 \mathrm{~g}$ showed the lowest growth parameters. It is also found that increasing protein or energy levels in red tilapia fry diets significantly increased feed intake (FI) and significantly improved feed conversion ratio (FCR) and protein efficiency ratio (PER). The best feed efficiency parameters (feed conversion ratio and protein efficiency ratio) were obtained for fish group fed the diet containing 35\% crude protein and $320 \mathrm{kcal} \mathrm{ME} / 100 \mathrm{~g}$ while the diet contained $25 \%$ crude protein and $320 \mathrm{kcal} \mathrm{ME} / 100 \mathrm{~g}$ diet had the worst FCR. Increasing dietary protein and energy levels in red tilapia fry diets significantly decreased protein and increased fat contents of red tilapia bodies. Generally, based on the present results, the experimental diet containing 35\% crude protein and 320 $\mathrm{kcal} \mathrm{ME} / 100 \mathrm{~g}$ considered the most suitable diet for red tilapia fry reared in fresh water.
\end{abstract}

Key words: Red tilapia, protein, energy, growth, nutrient utilization

\section{Introduction}

Tilapias are widely cultured in about 100 countries in tropical and subtropical regions. The first red tilapia produced in Taiwan in the late 1960s, was a cross between a mutant redish-orange female Mozambique tilapia and a normal male Nile tilapia. It was called the Taiwanese red tilapia. Another red strain of tilapia was developed in Florida in the 1970s by crossing a normal colored female Zanzibar tilapia with a red-gold Mozambique tilapia. A third strain of red tilapia was developed in Israel from a mutant pink Nile tilapia crossed with wild Blue tilapia (Popma and Masser, 1999). For the maximization of optimum growth rate and productivity of red tilapia, it is necessary to determine the protein and energy requirements of this fish under freshwater conditions. Since the protein content in finfish diets usually constitutes the largest single cost factor in feeds. Increasing protein level in diets can lead to improved fish production. However, excessive dietary protein level is not economical for fish culture because it is responsible for a large part of the feed cost. Dietary protein and energy levels are known to influence the growth and body composition of fish (Soltan et al., 2002). Insufficient energy in diets causes protein waste due to the increase of dietary protein proportion used for energy and produced ammonia can reduce the water quality. On the contrary, body lipid deposition and growth reduction were found because of a lack of necessary nutrient for growth (Daniels and Robinson, 1986). Therefore, it is important to improve the dietary protein utilization for body protein synthesis rather than for energy purposes. In addition, the optimization of the ratio of protein to energy play an important role in protein and energy utilization for fish (Kaushik, 1984).

The optimum protein level for tilapia has been the aim of many research studies in order to increase farm profitability. A wide range of $25-56 \%$ dietary crude protein level has been reported to be the protein level inducing maximum weight gain (Shiau et al., 1987; Siddiqui et al., 1988; El-Dahhar, 1994; Wu et al., 1995 and Soltan et al., 2002). Variation in protein requirements is due to different reasons; fish size, feeding rates, environmental conditions, protein and energy quality and their concentration in the diet. Providing the exact amount of energy in fish diets is important, because if the useful energy is too high the consumption of protein and other nutrients may be restricted and growth is retarded. Furthermore excess of energy may produce fatty fish. This can be undesirable especially if it reduces the dress-out yield and decrease the durability of the frozen fish (Lovell, 1989). On the other hand, when the diet is deficient in energy, dietary protein will be used as an energy source (Cowey, 1980). The more protein is used for energy, the more ammonia is produced, and the more energy is lost as heat (Cho and Kaushik, 1985), consequently, less protein will be retained in the fish body. Therefore, the proper balance between dietary protein and energy is therefore essential in fish feed formulation. The current study was conducted to evaluate the effect of dietary protein and energy levels on growth performance, nutrient utilization and body composition of red tilapia reared in freshwater.

\section{Materials and Methods}




\section{Preparation of the experimental diets}

Nine experimental diets were formulated to contain 3 protein levels, 25,30 or $35 \%$, within each protein level 3 energy levels were tested 240, 280 or $320 \mathrm{kcal} \mathrm{ME} / 100 \mathrm{~g}$ diet (Table 1). Formulation of the experimental diets is outlined in Table (2). All dry ingredients (fish meal, soybean meal, yellow corn and wheat bran) were thoroughly mixed with corn oil and vitamins \& minerals mixture, and then, passing the mixed feed through a laboratory pellet $(2-\mathrm{mm}$ die) in National institute of Oceanography and Fisheries, Cairo Governorate, Egypt (CMP California pellet Mill, San Francisco, CA, USA), and stored at $-20^{\circ} \mathrm{C}$ until used.

Table 1. Protein and energy content of the experimental diets.

\begin{tabular}{ccc}
\hline Experimental diets & Protein $(\%)$ & $\begin{array}{c}\text { Energy content } \\
\text { (Kcal/100g)ME }\end{array}$ \\
\hline D1 & 25 & 240 \\
\hline D2 & 25 & 280 \\
\hline D3 & 25 & 320 \\
\hline D4 & 30 & 240 \\
\hline D5 & 30 & 280 \\
\hline D6 & 30 & 320 \\
\hline D7 & 35 & 240 \\
\hline D8 & 35 & 280 \\
\hline D9 & 35 & 320 \\
\hline
\end{tabular}

Table 2. Composition and proximate analysis of the experimental diets.

\begin{tabular}{lccccccccc}
\hline \multicolumn{1}{c}{ Ingredients } & D1 & D2 & D3 & D4 & D5 & D6 & D7 & D8 & D9 \\
\hline Fish meal & 23.0 & 23.0 & 23.0 & 27.0 & 28.0 & 28.0 & 37.0 & 37.0 & 37.0 \\
\hline Soy bean meal & 24.0 & 24.0 & 24.0 & 34.0 & 34.0 & 34.0 & 31.0 & 30.0 & 31.0 \\
\hline Yellow corn & 21.0 & 23.0 & 29.0 & 14.0 & 14.0 & 13.0 & 10.0 & 19.0 & 18.0 \\
\hline Wheat bran & 26.0 & 19.0 & 11 & 19.0 & 13.0 & 8.0 & 16.0 & 6.0 & 0.0 \\
\hline Corn oil & 2.0 & 7.0 & 9.0 & 2.0 & 7.0 & 13.0 & 2.0 & 4.0 & 10.0 \\
\hline${ }^{1}$ Vit. \& mineral & 4.0 & 4.0 & 4.0 & 4.0 & 4.0 & 4.0 & 4.0 & 4.0 & 4.0 \\
\hline Sum & 100 & 100 & 100 & 100 & 100 & 100 & 100 & 100 & 100 \\
\hline
\end{tabular}

\section{Proximate analysis (based on dry matter}

\begin{tabular}{lccccccccc}
\hline Moisture\% & 4.93 & 5.55 & 4.67 & 4.80 & 5.60 & 4.91 & 5.19 & 5.50 & 5.46 \\
\hline Protein\% & 25.55 & 25.27 & 25.08 & 30.32 & 30.70 & 30.30 & 35.25 & 35.04 & 35.51 \\
\hline Fat\% & 5.80 & 9.83 & 14.80 & 6.00 & 9.94 & 14.72 & 6.10 & 9.525 & 14.40 \\
\hline Ash\% & 9.29 & 9.32 & 9.44 & 11.32 & 11.6 & 11.69 & 12.20 & 12.75 & 13.48 \\
\hline${ }^{2} \mathrm{ME}(\mathrm{kcal} / 100 \mathrm{~g})$ & 242 & 281 & 322 & 244 & 281 & 320 & 249 & 281 & 322 \\
\hline
\end{tabular}

${ }^{1}$ Each Kg vitamin \& mineral mixture premix contained Vitamin D3, 0.8 million IU; A, 4.8 million IU; E, 4 g; K, 0.8 g; B1, 0.4 g;

Riboflavin, 1.6 g; B 6 , 0.6 g, B 12,4 mg; Pantothenic acid, 4 g; Nicotinic acid, 8 g; Folic acid, 0.4 g Biotin, 20 mg , Mn, 22 g;

$\mathrm{Zn}, 22 \mathrm{~g} ; \mathrm{Fe}, 12 \mathrm{~g}$; Cu, $4 \mathrm{~g}$; I, $0.4 \mathrm{~g}$, Selenium, $0.4 \mathrm{~g}$ and Co, $4.8 \mathrm{mg}$,

${ }^{2}$ Estimated based on values of the diet ingredients (NRC, 1993)

\section{Fry Rearing}

Red tilapia fry were obtained from a finfish hatchery owned by GAFRD at Abu Telaat, west Alexandria. The experimental fish were transported in plastic bags filled with sea water and oxygen to the fish laboratory. Fish were adapted for two months by gradually decreasing water salinity and finally reared in fresh water. In the current study 27 rectangular aquaria $100 \times 40 \times 50 \mathrm{~cm}$ (200 liter for each) were used to represent 9 treatments (3 replicates for each treatment), and each aquarium was stocked with 40 red tilapia fry $(0.75-0.79 \mathrm{~g})$. Red tilapia fry were given the pelleted diets at a daily rate of $20 \%$ of the total biomass during the experimental period 6 day/week (twice daily at 9.00 am and $3.00 \mathrm{pm}$ ) and the amount of feed was bi-weekly adjusted according to the changes in body weight throughout the experimental period (60 day).
Growth performance and feed utilization parameters:

Records of live body weight (BW/g) and body length $(\mathrm{BL} / \mathrm{cm})$ of fish were measured in all fish for each pond and registered every 14 day (two weeks) during the experimental period. Growth performance parameters and feed utilization were measured by using the following equations:

Weight gain $(\mathrm{WG})=$ final weight $(\mathrm{g})$ - initial weight (g).

Specific growth rate $(\mathrm{SGR})=\frac{\operatorname{Ln} W 2-\operatorname{Ln} W 1}{t} x$

100

Where: $\mathrm{Ln}=$ the natural $\log ; \mathrm{W}_{1}=$ first fish weight; $\mathrm{W}_{2}$ $=$ the following fish weight in grams and $t=$ period in days. 
Feed conversion ratio $(\mathrm{FCR})=$ Feed ingested (g)/Weight gain $(\mathrm{g})$

Protein efficiency ratio $(\mathrm{PER})=$ Weight gain $(\mathrm{g}) /$ Protein ingested $(\mathrm{g})$

\section{Chemical analysis:}

At the end of the experiment, three fish were chosen at random from each aquaria and subjected to the proximate analysis of whole fish body. Moisture, dry matter (DM), ether extract (EE), crude protein (CP), crude fiber (CF) and ash contents of diets and fish were determined according to the methods described in AOAC (1990). dry matter after drying in an oven at $105^{\circ} \mathrm{C}$ until constant weight; ash content by incineration in a muffle furnace at $600^{\circ} \mathrm{C}$ for $12 \mathrm{hrs}$; crude protein $(\mathrm{N} \times 6.25)$ by the Kjeldhal method after acid digestion; and ether extract by petroleum ether $\left(60-80^{\circ} \mathrm{C}\right)$ extraction.

\section{Statistical analysis}

All data are presented as means \pm (SE). Growth, hematology and blood chemistry data were analyzed using one way ANOVA, followed by Duncan's multiple range tests (Duncan 1955) which was used to compare differences among individual means, with statistical software ANOVA procedure (SAS, 2004). A probability of 0.05 was utilized to account for the statistical difference between the means. Before the analysis, percentage data were normalized by arcsinetransformation.

\section{Results and Discussion}

\section{Growth performance of red tilapia fry:}

As presented in Table 3 averages of initial body weight $(\mathrm{BW})$ of red tilapia fry was $0.77 \mathrm{~g}$, body length (BL), $3.08 \mathrm{~cm}$ with insignificant $(\mathrm{P}>0.05)$ differences among the nine experimental fish groups, indicating the complete randomization of fish distribution among the nine treatments. At the experimental end it is obvious that, there were a significant differences in all growth performance parameters among the different fish groups (body weight, (BW), body length (BL), weight gain (WG) and specific growth rate (SGR) of red tilapia fry. These results may indicate that, protein requirements for red tilapia fry reared in tanks lie above $30 \%$ crude protein and these results are in complete accordance with El-Dahhar (1994) who found that WG of $O$. niloticus fry linearly increased with increasing diet crude protein contents. AbdelHakim and Mustafa (2000) found that dietary protein requirements for Nile tilapia, O. niloticus reared in cages and depending only on artificial feeds lie between 28-30\%. Also, Abdel-Hakim et al., (2001) demonstrated that, increasing dietary protein level from 25 to $30 \%$ significantly $(\mathrm{P}<0.05)$ increased fish BW, BL and SGR of Nile tilapia, O. niloticus reared in tanks. Wafa (2002) with hybrid tilapia (O. niloticus $\times$ O. aureus) and Soltan et al., (2002) with Nile tilapia (O. niloticus) found that, BW, BL and WG increased significantly $(\mathrm{P}<0.001)$ with increasing dietary protein from 25 to 30\%. Al-Hafedh (1999) found that, SGR of Nile tilapia was significantly increased as diet protein level increased from $25-45 \%$ (with increment of 5\%). On the other hand, Clark et al., (1990) found that SGR of Florida red tilapia did not differ significantly when fish fed diets contained 20, 25 or $30 \%$ crude protein.

The greatest final BW $(13.41 \mathrm{~g}), \mathrm{BL}(8.57 \mathrm{~cm})$ WG (12.64 g) and SGR (4.68\%) for red tilapia fry were achieved with the diet contained $35 \%$ protein and $320 \mathrm{kcal} \mathrm{ME} / 100 \mathrm{~g}$ diet. Also the lower final BW (6.22 g), BL(6.23 cm), WG (5.44 g) and SGR (3.42\%) were achieved with the diet contained $25 \%$ protein and 240 $\mathrm{kcal} \mathrm{ME} / 100 \mathrm{~g}$ diet. Results obtained in the present study are relatively consistent with Soltan et al., (2002) who found that the highest BW, BL, WG and SGR were achieved with the diet contained $30 \%$ protein and $3000 \mathrm{kcal} \mathrm{ME} / \mathrm{kg}$ and the lowest BW, BL, WG and SGR were achieved with the diet contained $20 \%$ protein and $3600 \mathrm{kcal} \mathrm{ME} / \mathrm{kg}$. Also, El-Dakar et al., (2011) indicated that, there were an improvement in all growth parameters of red tilapia as the dietary protein levels increased from 25 to $30 \%$ and the diet contained $30 \%$ protein and $20 \mathrm{MJ} \mathrm{Kg}^{-1}$ released the highest significant growth performance parameters for red tilapia fry. Similar results were obtained with blue tilapia, O. aureus, (Winfree and Stickney, 1981), $O$. niloticus (Teshima et al., 1985; Siddiqui et al., 1988 and El-Sayed and Teshima, 1992), Tilapia zilli (ElSayed, 1987), hybrid tilapia, $O$. niloticus $\times O$. aureus (Shiau and Huang, 1990). The different growth response to protein and energy levels in fish diets is probably due to dietary non-protein energy level (Kim and Lee, 2005). This indicates that $30 \%$ protein with $320 \mathrm{Kcal} \mathrm{ME} / 100 \mathrm{~g}$ diet has excess energy for red tilapia cultured in freshwater. Excessive dietary energy can lead to reduced growth of fish due to lacking of necessary nutrients for growth, resulting also from reduction in feed intake by fish (Daniels and Rebinson, 1986). Higher growth performance of red tilapia within dietary protein level of $30 \%$ and 320 $\mathrm{Kcal} / 100 \mathrm{~g}$ diet could be explained as this diet provided more energy for metabolization of protein to muscle tissue. On the other hand, fish received a lower dietary energy level $(240 \mathrm{Kcal} / 100 \mathrm{~g}$ diet could be utilizing part of dietary protein as energy source. The protein sparing effect evident when more energy is added to the diet and observed in tilapia hybrid, $O$. niloticus $\times O$. aureus (Shiau et al., 1987: Shiau and Huang, 1990). Fish groups fed the diet of $25 \%$ protein and $240 \mathrm{Kcal} \mathrm{ME} / 100 \mathrm{~g}$ (D1) and the diet of $30 \%$ protein and $280 \mathrm{Kcal} \mathrm{ME} / 100 \mathrm{~g}$ diet (D4) showed insignificant differences in final body weight and specific growth rate. These results suggest that red tilapia is capable of efficiently utilize dietary carbohydrates because this was the main non-protein energy source in the tested diets. Thus it is important to provide an adequate level and ratio of dietary protein and non-protein energy in order to reduce catabolism of protein for energy production. 
Table 3. Growth performance of red tilapia fry fed different dietary protein and energy levels

\begin{tabular}{lcccc}
\hline Diets & Body weight $(\mathrm{g})$ & Body length $(\mathrm{cm})$ & Weight gain & Specific growth rate \\
\hline D1 & $6.22 \mathrm{c}$ & $6.23 \mathrm{~b}$ & $5.45 \mathrm{c}$ & $3.42 \mathrm{~b}$ \\
\hline D2 & $6.74 \mathrm{c}$ & $6.74 \mathrm{~b}$ & $5.97 \mathrm{c}$ & $3.66 \mathrm{~b}$ \\
\hline D3 & $7.65 \mathrm{c}$ & $6.82 \mathrm{~b}$ & $6.76 \mathrm{~b}$ & $3.72 \mathrm{~b}$ \\
\hline D4 & $7.77 \mathrm{c}$ & $7.14 \mathrm{a}$ & $7.00 \mathrm{~b}$ & $3.90 \mathrm{~b}$ \\
\hline D5 & $9.10 \mathrm{ab}$ & $7.13 \mathrm{a}$ & $8.33 \mathrm{ab}$ & $4.07 \mathrm{a}$ \\
\hline D6 & $9.49 \mathrm{~b}$ & $7.21 \mathrm{a}$ & $8.70 \mathrm{ab}$ & $4.21 \mathrm{a}$ \\
\hline D7 & $10.40 \mathrm{ab}$ & $7.30 \mathrm{a}$ & $9.63 \mathrm{a}$ & $4.38 \mathrm{a}$ \\
\hline D8 & $11.39 \mathrm{~b}$ & $7.91 \mathrm{a}$ & $10.62 \mathrm{a}$ & $4.66 \mathrm{a}$ \\
\hline D9 & $13.41 \mathrm{a}$ & $8.57 \mathrm{a}$ & $12.64 \mathrm{a}$ & $4.68 \mathrm{a}$ \\
\hline Standard error & 0.42 & 0.13 & 0.06 & 0.03 \\
\hline + Means followed by the same letter in each column are not significantly different $(\mathrm{P}<0.05)$ &
\end{tabular}

+ Means followed by the same letter in each column are not significantly different $(\mathrm{P}<0.05)$.

\section{Feed intake and Feed utilization: \\ Feed intake}

Red tilapia fry fed the diet D9 (30\%CP and $320 \mathrm{Kcal}$ ME/100 g diet) consumed the highest (15.8 g/fish) amount of feed whereas fish group fed the diet D1 (25\% $\mathrm{CP}$ and $240 \mathrm{kcal} \mathrm{ME} / 100 \mathrm{~g}$ ) consumed the lowest amount of feed (12.15 g/fish). Total feed intake increased as dietary protein levels increased and not affected by energy level due to an increase in dietary protein level (Table 4). These results are in agreement with those obtained by El-Dakar et al., (2011) who indicated that feed intake for red tilapia fry was affected by dietary protein level and tend to increase with increasing dietary protein until level of 30\%. El-Dahhar (2000) reported that, feed consumption increased as dietary protein increased for tilapia fry. Also, Soltan et al., (2002) indicated that, increasing dietary protein from 20 to 25 or $30 \%$ in Nile tilapia diets significantly increased feed consumption. On the other hand, Cisse (1996), found that, a change in protein contents from 20 to $30 \%$ for tilapia fish did not have any significant effect on the quantity of feed consumed. El-Dahhar and Lovell (1995) described that, excess energy in tilapia diets may reduce feed consumption. Our results support those of Winfree and Stickney (1981) in that tilapia regulate their food consumption according to energy intake.

\section{Feed conversion ratio:}

Fish group fed the diet D9 $(35 \% \mathrm{CP}$ and $320 \mathrm{kcal}$ $\mathrm{ME} / 100 \mathrm{~g}$ ) showed the best improvement in FCR (1.25) and fish group fed the diet D1 (25\% CP and 240 kcal ME/100 g) showed the worst (2.39) FCR value for red tilapia fry (Table 4). These results mean showed that, the diet contained 35\% protein and $320 \mathrm{Kcal} / 100$ $\mathrm{g}$ diet considered the most suitable diet in the present study for red tilapia fry. Siddiqui et al., (1988), Cisse (1996), Abdel-Hakim et al., (2001) and Soltan et al., (2002). Al-Hafedh (1999) came to the same results that FCR of Nile tilapia was improved with increasing dietary protein level. El-Dahhar (1994) found that, FCR was significantly improved with increasing dietary protein level for both $O$. niloticus fry and the significant improvement in FCR was achieved when dietary protein level increased from 17 to $30 \%$ for fry and 17 to 22 for fingerlings. Wafa (2002) found that, hybrid tilapia $(O$. niloticus $\times O$. aureus) fed the diet with $\mathrm{P} / \mathrm{E}$ ratio of 100 showed the best FCR (3.22) followed by those fed the diet contained $80 \mathrm{mg}$ protein/kcal ME (3.27) while fish fed the diet contained $120 \mathrm{P} / \mathrm{E}$ ratio recorded the poorest $(\mathrm{P}<0.05)$ FCR values (3.44). Also, Soltan $\boldsymbol{e t}$ al., (2002) found that the best FCR was obtained with tilapia fish group fed the experimental diet contained $30 \% \mathrm{CP}$ and $3000 \mathrm{Kcal} \mathrm{ME} / \mathrm{kg}$ diet (P/E ratio of 100 $\mathrm{mg}$ protein/kcal). In studies deal with different dietary protein levels, diet which exhibited a higher weight gain and growth usually exhibited, at the same time a higher feed conversion ratio (lower values) as was obtained by Shiau and Huang (1990).

\section{Protein efficiency ratio (PER):}

Protein efficiency ratio (PER) values were improved for fry fed the diet contained 35\% CP and $320 \mathrm{kcal} \mathrm{ME} / 100 \mathrm{~g}$ diet (Table 4). Soltan et al., (2002) reported that, the best PER for Nile tilapia was recorded for fish group fed the diet contained 30\% CP and $3000 \mathrm{Kcal} \mathrm{ME} / \mathrm{kg}$ (P/E ratio of 100) and the lowest was recorded for the diet contained 25\% CP and 3000 $\mathrm{Kcal} / \mathrm{kg}$ diet. Twibell and Brown (1998) found that, PER was unaffected by increasing dietary protein from 25 to $35 \%$ for $O$. niloticus. On the other hand, Siddiqui et al., (1988) found that, PER decreased with increasing diet protein level from 20 to $50 \%$ for Nile tilapia. Also, El-Ebiary (1994) found that, increasing dietary protein level up to $35 \%$ and feeding rate up to $4 \%$ decreased the values of nutrients (protein and energy) utilization in Nile tilapia and its hybrid. Also, El-Dakar et al., (2011) showed that PER was significantly affected by dietary protein and energy levels whereas PER had a negative relationship with dietary protein level. At 25 and $30 \%$, increasing dietary energy level form 240 to $280 \mathrm{Kcal} / 100 \mathrm{~g}$ diet improved growth rate, feed intake, FCR and PER. These results are in partial; accordance with those reported with tilapia freshwater species by Shiau and Huang (1990), Wafa (2002) and (El-Dakar et al., 2011).

\section{Proximate analysis of red tilapia:}

Chemical analysis at the end of a feeding trial is frequently used to determine the influence of feed on fish composition (Hafez et al., 2000; Abdel-Hakim et al., 2001). According to Hepher (1990), endogenous 
factors (size, sex and stage of life cycle) and exogenous factors (diet composition, feeding frequency, temperature etc.) affect the body composition of fish. It should be noted that within endogenous factors, feed composition is only factor, which could have influenced the chemical composition of fish, as other endogenous factors were maintained uniform during the study. Proximate analysis of the present study showed that, dry matter content in whole fish bodies ranged between 27.10 to $29.78 \%$, protein content from 55.34 to $59.34 \%$, fat ranged between 25.33 to $30.44 \%$ and ash from 12.23 to $15.44 \%$ for red tilapia fry fed the different experimental diets that contained different protein and energy levels and fish fed the different experimental diets had a significant effect on the percentages of protein, fat and ash content of red tilapia fry (Table 5) and these results were supported by Abdel-Hakim et al., (2001) who found that, increasing dietary protein level from 25 to $30 \%$, decreased the percentages of protein from 55.58 to 52.24\%. Also, Al-Hafedh (1999) found no significant influence of dietary protein level (25 to $45 \%$ ) on body protein content of Nile tilapia but the lipid content decreased with increasing protein level and no clear trends in ash content were observed. Shiau and Huang (1990) and Soltan et al., (2002) indicated that, body lipid increased as dietary energy increased while the moisture, protein and ash contents decreased. Similar results were also reported with Mozambique tilapia (El-Dahhar and Lovell, 1995). ElDakar et al., (2011) showed that, moisture, lipids, protein and energy were affected by dietary protein level but not affected by energy level. The body moisture, lipids, protein and energy contents tended to increase with increasing protein level from 25 to $35 \%$.

Table 4. Parameters of feed utilization for red tilapia fry fed different dietary protein and energy levels.

\begin{tabular}{lccc}
\hline Diets & Feed intake (FI) (g/fish) & $\begin{array}{c}\text { Feed conversion } \\
\text { Ratio (FCR) }\end{array}$ & Protein efficiency ratio (PER) \\
\hline D1 & $12.15 \mathrm{c}$ & $2.24 \mathrm{~b}$ & $1.75 \mathrm{c}$ \\
\hline D2 & $12.15 \mathrm{c}$ & $2.03 \mathrm{c}$ & $1.95 \mathrm{~b}$ \\
\hline D3 & $16.36 \mathrm{a}$ & $2.40 \mathrm{a}$ & $1.66 \mathrm{~d}$ \\
\hline D4 & $14.31 \mathrm{~b}$ & $2.04 \mathrm{c}$ & $1.62 \mathrm{~d}$ \\
\hline D5 & $15.53 \mathrm{a}$ & $1.87 \mathrm{~d}$ & $1.74 \mathrm{c}$ \\
\hline D6 & $14.85 \mathrm{~b}$ & $1.70 \mathrm{~d}$ & $1.75 \mathrm{~b}$ \\
\hline D7 & $15.80 \mathrm{a}$ & $1.64 \mathrm{e}$ & $1.73 \mathrm{c}$ \\
\hline D8 & $15.53 \mathrm{a}$ & $1.45 \mathrm{f}$ & $2.96 \mathrm{~b}$ \\
\hline D9 & $15.80 \mathrm{a}$ & $1.25 \mathrm{~g}$ & 0.02 \\
\hline Standard error & 0.04 & 0.02 & \\
\hline
\end{tabular}

+ Means followed by the same letter in each column are not significantly different $(\mathrm{P}<0.05)$.

Table 5. Proximate analysis (\%) of red tilapia fry fed different dietary protein and energy levels.

\begin{tabular}{lcccc}
\hline Diets & Dry matter & Protein & Fat & Ash \\
\hline D1 & 29.50 & $56.33 \mathrm{~b}$ & $30.29 \mathrm{a}$ & $13.16 \mathrm{bc}$ \\
\hline D2 & 29.30 & $56.23 \mathrm{~b}$ & $30.34 \mathrm{a}$ & $14.00 \mathrm{~b}$ \\
\hline D3 & 29.78 & $55.34 \mathrm{c}$ & $30.44 \mathrm{a}$ & $13.34 \mathrm{bc}$ \\
\hline D4 & 27.67 & $56.54 \mathrm{~b}$ & $26.54 \mathrm{~b}$ & $15.44 \mathrm{a}$ \\
\hline D5 & 28.45 & $57.45 \mathrm{~b}$ & $25.44 \mathrm{c}$ & $13.26 \mathrm{bc}$ \\
\hline D7 & 28.78 & $56.11 \mathrm{~b}$ & $25.33 \mathrm{c}$ & $13.55 \mathrm{bc}$ \\
\hline D8 & 27.10 & $57.25 \mathrm{~b}$ & $25.36 \mathrm{c}$ & $14.32 \mathrm{~b}$ \\
\hline D8 & 29.12 & $59.34 \mathrm{a}$ & $27.13 \mathrm{~b}$ & $12.42 \mathrm{c}$ \\
\hline D9 & 28.45 & $57.27 \mathrm{~b}$ & $30.11 \mathrm{a}$ & $12.23 \mathrm{c}$ \\
\hline Standard error & 0.63 & 2.13 & 1.40 & 1.00 \\
\hline
\end{tabular}

+ Means followed by the same letter in each column are not significantly different $(\mathrm{P}<0.05)$.

\section{Conclusion}

The results of this study indicated that, the diet containing $35 \%$ protein and $320 \mathrm{Kcal} \mathrm{Me} / 100 \mathrm{~g}$ diet is the optimal for growth and effective protein utilization of red tilapia reared in freshwater.

\section{References}

Abdel-Hakim, N.F. and Mustafa, S.T. (2000). Performance of Nile tilapia (Oreochromis niloticus) raised in cages as affected with stocking density and dietary protein level. Egyptian Journal of Aquatic Biology and Fisheries, 4:95.

Abdel-Hakim, N.F., Hussein, M.S., Bakeer, M.N. and Soltan, M.A. (2001). Effect of protein level and stocking density on growth performance of Nile tilapia (Oreochromis niloticus) cultured in tanks. Egyptian J. Nutrition and feed, 4 (Special Issue) : 763-780.

Al-Hafedh, Y.S. (1999). Effects of dietary protein on growth and body composition of Nile tilapia, 
Oreochromis niloticus L. Aquaculture Resources, 30:385-393.

AOAC (1990). Official Methods of Analysis. Association of official Analytical chemists. Washington, D. C.

Cho, C.Y. and Kaushik, S.J. (1985). Effect of protein intake on metabolism and net energy values of fish diets. In: C. B., Cowey, A. M. Mackie and J. G. Bell (Editors), Nutrition and Feeding in Fish. Academic Press, London, pp, 96-117.

Cisse, A. (1996). Effects of the varying protein-energy levels on food consumption, growth and body composition of Sarotherodon melanotheron (Rüppel, 1852). P 193-197. In R.S.V. Pullin, J. Lazard, M. Legendre, J. B. Amon Kothias and D. Pauly (eds.). The third international Symposium on tilapia in Aquaculture. ICLARM Conf. Proc. 41, $575 \mathrm{p}$.

Clark, A.E., Watanabe, W.O. Olla, B.L. and Wicklund, R.I. (1990). Growth, feed conversion and protein utilization of Florida red tilapia fed isocaloric diets with different protein levels in seawater pools. Aquaculture, 88:75-85.

Cowey, C.B. (1980). Protein and amino acid requirements in fish. In H. J.Oslage and K. Rohr (Editors), Proc. Eur. Aquacult. Assoc. Symp. Protein Metabolism and Nutrition, EAAP Publication no. 27, pp. 729-774. Finfish. Nutr. and feed technol., Hamburg. FLFC/78/symp. R 16.

Daniels, W.H. and Robinson, E.H. (1986). Protein and energy requirements for juvenile red drum (Sciaeenop ocellatus). Aquaculture, 53:243-252.

Duncan, D.B. (1955). Multiple range and multiple F test. Biometrics, 11:1-42.

El-Dahhar, A.A. (2000). Developing a feeding guide for Nile tilapia Oreochromis niloticus based on dietary protein levels fed. Conference of Social and Agricultural Development of Sinai, El-ArishNorth Sinai, 16-19 May, Egypt, 127-138.

EI-Dahhar, A.A. (1994). Protein requirements of fry and fingerlings of Nile Tilapia (Oreochromis niloticus) fed at varying protein level in Egypt. J. Agric. Sci. Mansoura Univ. 19 (1). 117- 128.

El-Dahhar, A. A. and Lovell, R. T. (1995). Effect of protein to energy ratio in purified diets on growth performance, feed utilization and body composition of Mozambique tilapia, Oreochromis mossambicus (peters). Aquaculture, 26: 451-457.

El-Dakar, A.Y., Shymaa M. Shalaby and Asmaa I. Abd Elmonem (2011). Interactions of dietary protein and energy levels with special references to protein sparing effect of hybrid tilapia, Oreochromis niloticus (Linnaeus) $\times$ Oreochromis mosambicus (Peters) reared in seawater. Asian Pacific Aquaculture \& Giant Prawn, Kochi, India, 2011.

El-Ebiary, E.H. (1994). Studies on fish production: Relationship between nutrition and reproduction of tilapia sp. Ph.D. Thesis, Fac. of Agric., Alex. University.
El-Sayed, A.M. (1987). Protein and energy requirements of Tilapia Zilli Ph.D. Thesis., Michigan State University East lansing MI, USA, 147 PP.

El-Sayed, A.M. and Teshima, S. (1992). Protein and energy requirements of Nile Tilapia Oreochromus niloticus fry. Aquaculture, 103: 55-63.

Hafez, F.A., Soltan, M.A. and Ibrahim, M. K. (2000). Effect of organic fertilization, supplementary feeding and stocking rate on carcass and chemical composition of Nile tilapia and silver carp. Egypt. J. Agric., Res., 78 (5):21272143.

Hepher, B. (1990). Ingestion, digestion and absorption of food. In: B. Hepher, (Ed.). Nutrition of Pond Fishes. Academic Press, Cambridge, pp, 16-63.

Kaushik, S.J. (1984). Nutritional strategies for the reduction of requirements wastes. Proceeding of FOID "94 the Third International Conference on Fisheries and Ocean Industrial Development for Productivity Enhancement of the Coastal Waters. Pusa, Korea, 115-132.

Kim, L.O. and Lee, S.M. (2005). Effect of dietary protein and lipid levels in growth and body composition of bagrid catfish (Pseudobagrus fulvidraco). Aquaculture, 243:323-329.

Lovell, R.T. (1989). Nutrition and feeding of fish. Van Nostrand Reinhold, New York, NY, 260 pp.

NRC (1993). Nutrient requirements of fish, $114 \mathrm{pp}$. National Research Council Washington, DC.

Popma, T. and Masser, M. (1999). Tilapia, Life History and Biology. Southern Regional Aquaculture Center. SRAC Publication No. 283.

SAS (2004). SAS Procedure Guide version 6.12 Ed. SAS Institute Inc., Cary, NC, USA.

Shiau S.Y. and Huang, S.L.(1990). Influence of varying energy levels with two protein concentration in diets for hybrid tilapia (Oreochromis niloticus $\times O$. aureus) reared in seawater. Aquaculture, 91: 143-152

Shiau S.Y., Chuang, J.L. and Sun. C.L. (1987). Inclusion of soybean meal in tilapia (Oreochromis niloticus $\times O$. aureus) diets at two protein levels. Aquaculture, 65: 251-261

Siddiqui, A., Howlader, M.S. and Adam, A. A. (1988). Effects of dietary protein level on growth, feed conversion and utilization in fry and young Nile tilapia, Oreochromis niloticus. Aquaculture, 70: 6373.

Soltan, M.A., Radwan, A.A. and Samra, I.M. (2002). Effect of varying protein, energy and protein to energy ratio on growth, feed efficiency and body composition of Nile tilapia, Oreochromis niloticus. The $1^{\text {st }}$ Annual Conference of the Egyptian Aquaculture Society, Al-Aresh, North Sinai, Egypt, 13-15 December, 2000.

Teshima, S., Kanazawa, A. and Uchiyama, Y. (1985). Optimum protein levels in casein gelatin diets for tilapia nilotica. Mem. Fac. Fish Kagoshima Univ., 34: 45-52. 
Twibell, R.G. and Brown, P.B. (1998). Optimal dietary protein concentration for hybrid tilapia, Oreochromis niloticus $\times O$. aureus fed all-plant diets. Journal of the world aquaculture Society, 29: 9-16.

Wafa, M.E. (2002). Nutrient requirements of Nile tilapia. Ph.D. Thesis, Fac. Agric. Moshtohor, Zagazig University (Banha branch).
Winfree, R.A. and Stickney, R.R. (1981). Effect of dietary protein and energy on growth, feed conversion efficiency and body composition of Tilapia aurea. J. Nutr., 111: 1001- 1012.

Wu, Y.V., Rosati, R., Sessa, D.J. and Brown, P. (1995). Utilization of corn gluten feed by Nile tilapia. The progressive fish-culturist 57: 305-309. 


\section{تأثير مستويات مختلفة من البروتين والطاقة على أداء النمو ومكونات الجسم لزريعة أسماك البلطى الأحمر محمد يحيى أبوزيد}

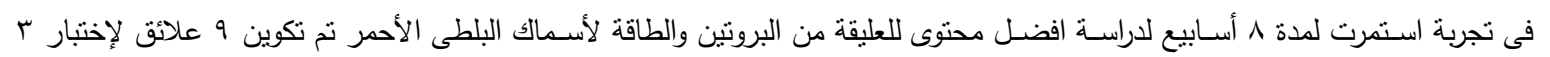

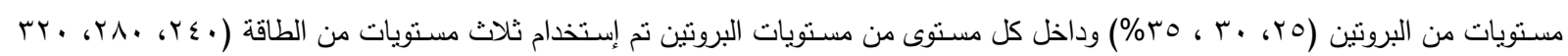

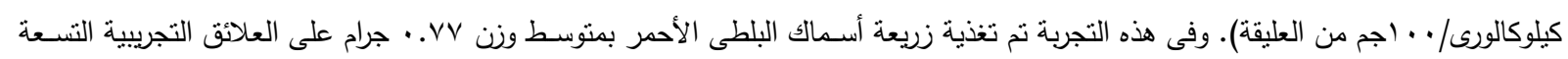

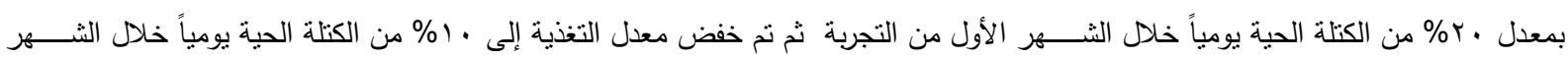

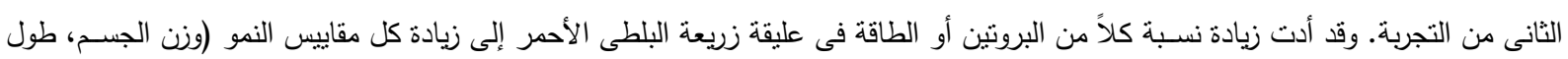

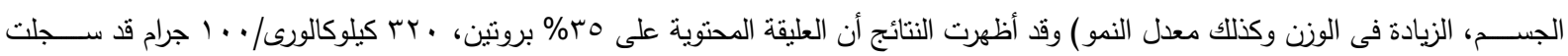

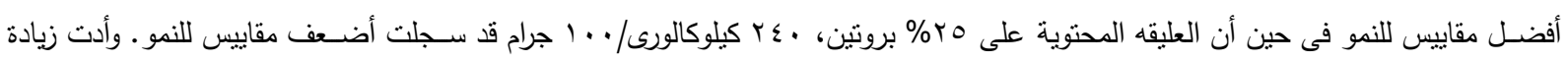

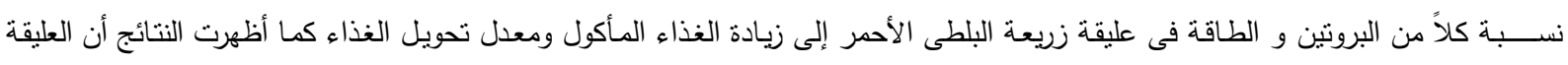

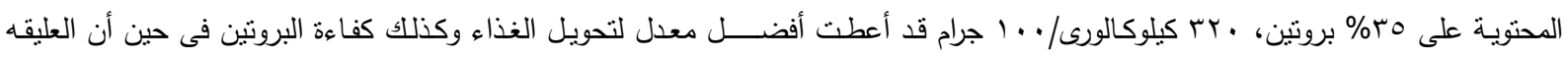

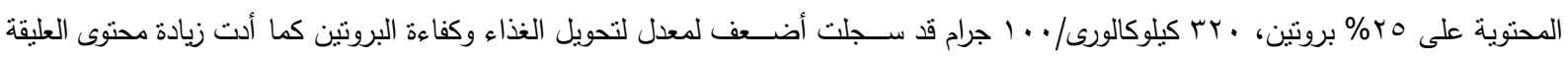

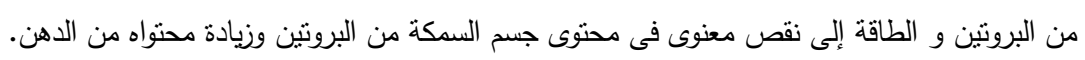

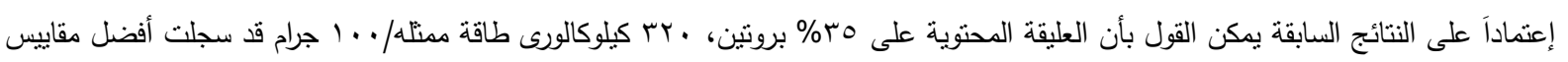
اللنمو وكذلك كفاءة إستخدام الغذاء. 